\title{
Long-term changes in surface-active beetle communities in a post-fire successional gradient in Pinus brutia forests
}

Burçin Yenisey Kaynaş

\section{Introduction}

Pinus brutia is the dominant tree of old growth forests in the Aegean, Marmara, and Mediterranean regions of Turkey. Such forests range from the sea level up to $700-$ $800 \mathrm{~m}$ in the Aegean region and $1500 \mathrm{~m}$ in the Mediterranean region (Kaya \& Rayna 2001). Fire is an integral part of many ecosystems such as the Mediterranean and it serves as a strong selective force on plant and animal communities (Thanos \& Marcou 1989). As one of the most important ecological factors, fire has been studied comprehensively in these ecosystem types. Much attention has been paid to vegetational changes and regeneration strategies of plant communities in Mediterranean forests. Because dynamic feedbacks between

$\square$ Mehmet Akif Ersoy University, Faculty of Science and Arts, Department of Biology, Istiklal Campus, Burdur (Turkey)

@ Burçin Yenisey Kaynaș (bykaynas@mehmetakif.edu.tr)

Received: Jun 16, 2016 - Accepted: Oct 12, 2016

Citation: Kaynaș BY (2017). Long-term changes in surface-active beetle communities in a post-fire successional gradient in Pinus brutia forests. iForest 10: 376-382. - doi: 10.3832/ifor2140-009 [online 2017-03-16]

Communicated by: Massimo Faccoli ties. plants and their consumers influenced the response of the whole ecosystem, incorporating higher trophic level responses into the pool of knowledge regarding fire effects is essential (Kim \& Holt 2012).

Effects of fire on insects and other arthropods can operate through a variety of mechanisms at different temporal scales (Andersen \& Müller 2000). Direct effects of fires include mortality, forced emigration (Whelan 1995), or immigration of pyrophilous insects (Wikars \& Schimmel 2001, Wikars 2002). The sensitivity of fire effects depends on biological characteristics such as trophic level, seasonal activity, and vertical distribution (Prodon et al. 1987). Indirect or long-term effects of fire depend substantially on habitat changes. Following

Fire is one of the most important ecological factors for many ecosystem types. Since prehistoric times, synergistic effects of fires and humans have led to changes in Eastern Mediterranean ecosystems. The effects of fire on different trophic levels, particularly regarding plants, have been examined intensively in fire-induced ecosystems. In this study, we aimed to study long-term changes in beetle community structure after fire in Pinus brutia Ten. forests. Five sites burned in different years and a control site unburned for at least 50 years were selected. Beetle sampling was conducted using four pit-fall traps in each of four transects in three replication plots at every successional site and in two plots at the control site. Microhabitat variables related to vegetation structure and litter layer were recorded and associated with abundances of beetles and feeding groups. The results showed that total, wood-eating, and predator beetles showed a decreasing trend of abundance along the successional gradient after fire. In contrast to these groups, herbivores tended to increase towards the late successional stages. Middle and late successional stages were important in terms of species richness, species diversity and evenness of beetle communities and feeding groups. The characteristics of vegetation and litter layer changed with successional gradient, playing a decisive role in the structure of beetle communities at successional sites. According to the data presented here, a mosaic structure consisting of different successional stages is very important to sustain high species diversity in beetle communi-

\section{Keywords: Forest Fires, Coleoptera, Brutia Pine, Resilience, Autosuccession}

fire, changes in plant species' composition, plant diversity (Lawton 1983, Siemann 1998, 1999), and plant architecture (Southwood et al. 1979, Lawton 1983) influence the diversity and richness of insect communities. In Mediterranean ecosystems, a general model concerning response to fire at population or community scale is not possible, but on a regional scale, two resiliency components, elasticity and inertia, along with the mosaic pattern of the fires and the possibilities of local emigration and emigration result in relative stability of the animal communities (Prodon et al. 1987). At the functional scale, greater stability is achieved by replacement of functionally similar species that dominate under different environmental conditions in the heterogeneous parts of the region (Moretti et al. 2009).

Beetles form the largest order in the animal kingdom, with over a third of a million described species (Booth et al. 1990). They are commonly used in ecological monitoring studies, as they display assemblagelevel responses to habitat change and can be a more direct measure of the recommencement of some ecosystem functions (Leach et al. 2013). The aim of the present study was to investigate the long-term response of beetle communities to habitat change depending on successional gradient after fire. The existence of beetles in all 
consumer trophic levels allows evaluation of the responses of these groups. In the present study, beetle community composition was also assessed by feeding groups to determine whether the their abundance differed among post-fire successional sites.

\section{Material and methods}

\section{Study area}

The study was carried out in several Pinus brutia forests located in the Marmaris region $\left(36^{\circ} 50^{\prime} \mathrm{N}, 28^{\circ} 17^{\prime} \mathrm{E}\right)$ and its surrounding areas, which is situated on the Mediterranean coast of southwestern Turkey. This area has a typical Mediterranean climate with hot and dry summers. The total precipitation is $1211.7 \mathrm{~mm}$ year $^{-1}$ (between 1975 and 2006), with a dry period lasting 5 months from May to September. Monthly mean temperatures range from $10.6{ }^{\circ} \mathrm{C}$ in January to $28.3{ }^{\circ} \mathrm{C}$ in July. The dominant vegetation of the area is P. brutia forest and these forests are characterized by fire-created habitat mosaic consisting of many sites at different stages of succession.

The study sites were selected from P. brutia forests burned at different times in the area. The successional gradient consisted of five areas burned 3, 6, 9, 16, and 26 years ago and an area unburned for at least 50 years. The samplings were performed at three replication sites for every successional site and at two for the unburned forests. All sampling sites were selected in the central part of the burned areas, where crown fires formerly caused the complete destruction of vegetation and aboveground layer. The sites were located apart from unburned forest at least $1000 \mathrm{~m}$.

\section{Insect sampling}

Beetles were sampled with four pit-fall traps that were placed along a transect at 10-m intervals. Four transects were used at every replication site. The traps consisted of plastic jars of about $7 \mathrm{~cm}$ in diameter buried in the soil up to the rim and halffilled with 30\% ethylene alcohol. Sampling was carried out from March to October of 2006. At the end of each sampling period insects caught in the pitfall traps were removed and brought to the laboratory for preparation. All caught beetles were sorted into morphospecies according to their external morphology and identified to family level.

\section{Habitat Measurement}

Microhabitat structure of the sites was analyzed with the point quadrat technique (Sutherland 2006). For every transect at each replication site, two trap locations were selected for measurement of microhabitat attributes. In each measurement location nine points were selected; one was at the center and the remaining eight were situated in four different directions around the trap. At each point, the plant

Tab. 1 - Beetle families from pitfall catches, their feeding habits and mean abundance per replication site in successional sites.

\begin{tabular}{llcccccc}
\hline \multirow{2}{*}{ Families } & Feeding & \multicolumn{7}{l}{ Time since fire (years) } & & & \\
\cline { 2 - 8 } & habits & $\mathbf{3}$ & $\mathbf{6}$ & $\mathbf{9}$ & $\mathbf{1 6}$ & $\mathbf{2 6}$ & $>\mathbf{5 0}$ \\
\hline Anobiidae & xylophagous & - & 0.3 & - & 0.3 & - & - \\
\hline Apionidae & herbivore & 0.3 & 1.0 & - & - & - & - \\
Bolboceratidae & saprophagous & - & - & 0.7 & - & - & - \\
\hline Bruchidae & granivore & 0.3 & - & 0.3 & 0.7 & - & - \\
\hline Buprestidae & xylophagous & 220.0 & 26.0 & 78.3 & 91.0 & 55.7 & 18.0 \\
\hline Carabidae & predator & 41.0 & 5.0 & 30.0 & 5.0 & 5.0 & 2.0 \\
\hline Cerambycidae & xylophagous & - & - & 0.7 & 0.7 & 0.3 & - \\
\hline Chrysomelidae & herbivore & 0.3 & 0.3 & 0.3 & - & - & - \\
\hline Cleridae & predator & 80.3 & 3.3 & 4.0 & 16.7 & 11.0 & 5.5 \\
\hline Cucujidae & saprophagous & - & 0.3 & - & 1.0 & 0.7 & 0.5 \\
\hline Curculionidae & herbivore & - & - & 0.7 & 2.0 & 0.7 & - \\
\hline Dermestidae & saprophagous & 0.3 & 0.7 & 0.3 & - & - & 0.5 \\
\hline Elateridae & various & - & 1.0 & 0.7 & 0.3 & - & - \\
\hline Glaphyridae & saprophagous & 0.7 & 0.7 & 8.0 & 1.7 & 2.3 & - \\
\hline Geotrupidae & saprophagous & 0.3 & 0.7 & 0.3 & 1.0 & 0.7 & 1.0 \\
\hline Lucanidae & various & - & - & - & - & 0.3 & - \\
\hline Meloidae & herbivore & 4.7 & 1.3 & 4.0 & 7.0 & 1.0 & 0.5 \\
\hline Mordellidae & herbivore & 4.3 & 2.7 & 3.7 & 9.0 & 13.7 & 0.5 \\
\hline Nitidulidae & saprophagous & - & - & 1.0 & - & - & - \\
\hline Oedemeridae & herbivore & 0.3 & - & 1.0 & 1.7 & 0.3 & 1.0 \\
\hline Orphnidae & herbivore & - & - & - & 1.0 & 4.0 & - \\
\hline Rutelidae & herbivore & 2.0 & 1.0 & 1.3 & - & 1.0 & - \\
\hline Scarabaeidae & saprophagous & 5.0 & 4.0 & 3.0 & 2.0 & 1.0 & 3.0 \\
\hline Scolytidae & xylophagous & 7.3 & 2.0 & 3.0 & 11.0 & 2.7 & 13.5 \\
\hline Staphylinidae & predator & 8.7 & 2.7 & 4.0 & 4.7 & 11.3 & 10.0 \\
\hline Tenebrionidae & various & 65.3 & 118.7 & 104.3 & 18.0 & 23.7 & 3.5 \\
\hline & & & & & & & \\
\hline
\end{tabular}

species were identified, the height of plant at this point was measured, and the surface characteristics were recorded.

Habitat variables measured at each site were height and total cover of vegetation, plant species richness, cover of plant functional types (tree, shrub, subshrub, and grass) and cover of biotic and abiotic surface components.

\section{Statistical analysis}

To test the statistical significance of any changes in abundances of beetles and feeding groups among successional stages, the analysis of variance (ANOVA) was applied. Total counts during sampling were used. In the ANOVA, abundances were expressed as mean number of individuals per four traps in a transect. Square root and logarithmic transformations were used when the data did not meet the parametric assumptions. Overall, six successional stages were compared using means of abundances from transects at the replication sites. Linear regression was used to test change in beetle abundance along the successional gradient. Linear regression was also used to examine interactions between microhabitat variables and feeding groups. The following community parameters were estimated for each successional site: species richness (number of species), species diversity Shannon index $\left(H^{\prime}=-\sum p_{\mathrm{i}} \log p_{\mathrm{i}}\right.$, where $p_{\mathrm{i}}$ is the relative abundance of the $i^{\text {th }}$ species) and evenness $\left(E^{\prime}=H^{\prime} \mid \log S\right.$, where $S$ is the number of species). Specialist species to a certain successional stage and generalist species were estimated. Species that made up over 90\% of collected individuals in certain successional sites were evaluated as specialist species for that site.

The relationship between beetle abundance among sampling sites and microhabitat variables was estimated using ordination techniques. A canonical correspondence analysis (CCA) using the CANOCO version 4.5 software package (Ter Braak \& Smilauer 2002) was used to assess habitat preferences of microhabitat variables in relation to successional stages. Twelve microhabitat variables were used in the analysis. The statistical significance of the canonical axes was tested using Monte Carlo permutations. Microhabitat variables were added one by one to the model, starting from the most important one, until the subsequent variable was statistically nonsignificant. The analysis was constrained by microhabitat variables measured for each site, which are indicated with arrows that represent the direction strength of their correlations.

\section{Results}

A total of 3425 beetles comprising 121 morphospecies from 26 families were collected (Tab. 1). The most abundant families were Buprestidae (41\%) and Tenebrionidae (28\%). The mean number of beetles per trap tended to decrease along the succes- 
Fig. 1 - Number of individuals, species and specialist species, species diversity and evenness values for beetle communities at successional sites (mean \pm standard deviation)
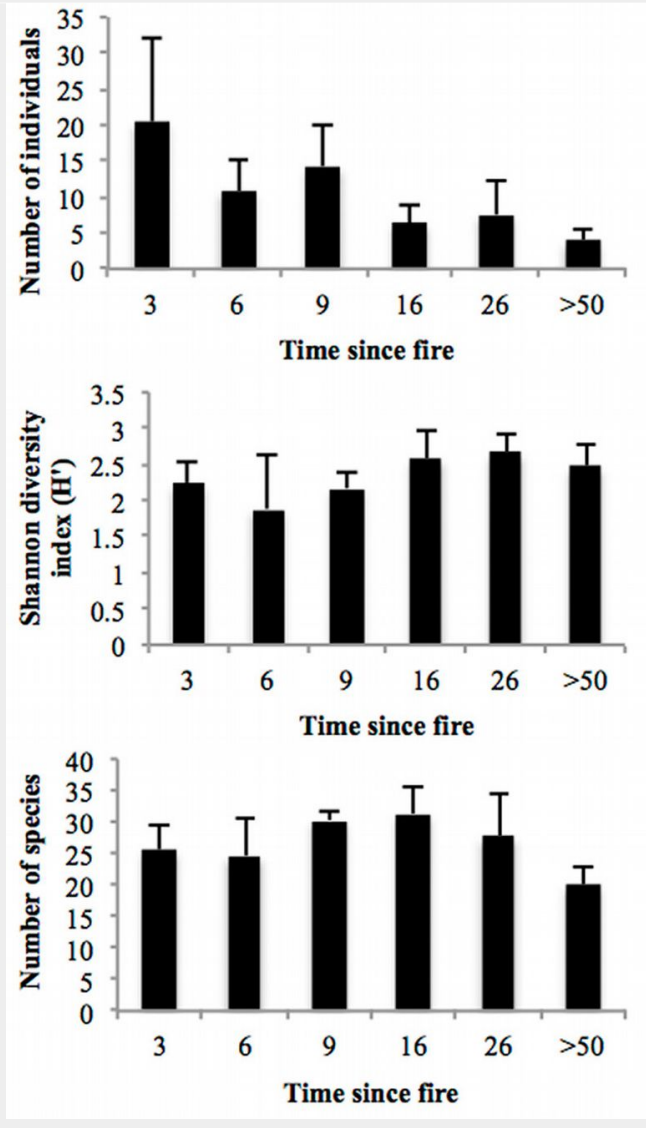
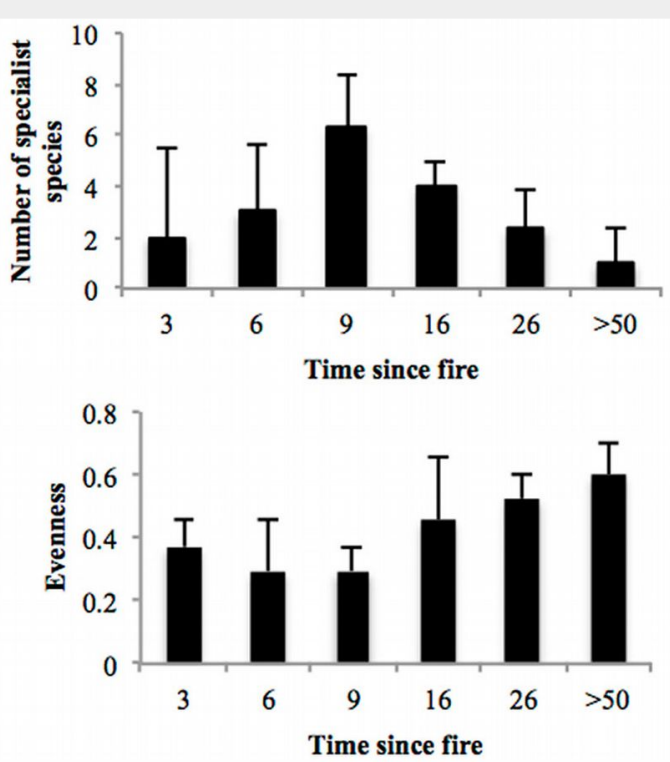

sional gradient $\left(R^{2}=0.298 ; \mathrm{df}=5 ; \mathrm{p}<\right.$ 0.0001), despite the rises at sites burned 9 and 26 years previously that deviated from the downward tendency (Fig. 1). The abundance value for the earliest stage was significantly greater than that of all other successional stages. The site burned 9 years previously had the second most abundant beetle community and it was significantly different than the site burned 16 years previously and the control site $(\mathrm{F}=21.049$; $\mathrm{df}=$ 5; $\mathrm{p}<0.0001)$. However, species diversity and evenness values were higher in the late successional sites in comparison with the earlier stages (Tab. 2). The number of specialist species was highest at the site burned 9 years previously and declined towards the early and late successional stages (Fig. 1). Fifteen species of the total were generalist, well represented at all sites. CCA revealed interactions between microhabitat variables and successional sites in terms of beetle abundance (Fig. 2). The sum of eigenvalues was 2.071 and the eigenvalues of the first two axes were 0.338 and 0.254 , respectively. These axes explained $28.6 \%$ of the cumulative variance of the species data and $36.7 \%$ of the species-environment relationship. The height of vegetation, tree cover, vegetation stratification, and plant species richness at the upper right side of the ordination and mature pine sites (sites unburned for at least 50 years) were highly correlated with these microhabitat variables. Most of the middle and late successional sites (from the site burned 6 years before to the site burned 26 years before) were associated with leaf and shrub cover. Vegetation height and leaf cover were the two significant variables associated with beetle abundance $(F=2.047, p=0.006$ and $F=1.875, p$ $=0.006$, respectively). The earliest successional sites were just correlated with bare soil cover at the bottom right side.

Of the beetles that could be placed into feeding guilds, there were more xylophages (55.6\% of individuals) than any

Tab. 2 - Species richness, species diversity and evenness values for feeding groups of beetle communities at successional sites (mean \pm standard deviation).

\begin{tabular}{llcccccc}
\hline \multirow{2}{*}{ Parameter } & \multirow{2}{*}{ Feeding Groups } & \multicolumn{6}{l}{ Time since fire (years) } \\
\cline { 3 - 7 } & & $\mathbf{3}$ & $\mathbf{6}$ & $\mathbf{9}$ & $\mathbf{1 6}$ & $\mathbf{2 6}$ & $>$ \\
\hline Species & Herbivores & $4.500 \pm 3.5$ & $4.500 \pm 1.5$ & $6.000 \pm 1.7$ & $6.667 \pm 2.1$ & $4.333 \pm 2.1$ & $2.000 \pm 1.4$ \\
richness & Xylophagous & $8.000 \pm 1.0$ & $8.333 \pm 1.5$ & $7.333 \pm 1.5$ & $9.000 \pm 1.7$ & $7.333 \pm 1.2$ & $5.000 \pm 0.0$ \\
& Predators & $8.333 \pm 1.5$ & $4.667 \pm 2.1$ & $8.333 \pm 0.6$ & $9.000 \pm 2.6$ & $8.667 \pm 0.6$ & $7.500 \pm 0.7$ \\
& Saprophagous & $2.667 \pm 2.1$ & $4.000 \pm 2.6$ & $4.667 \pm 1.2$ & $4.667 \pm 1.5$ & $5.000 \pm 3.5$ & $3.500 \pm 0.7$ \\
Species & Herbivores & $1.165 \pm 0.4$ & $0.995 \pm 0.5$ & $1.552 \pm 0.4$ & $1.514 \pm 0.2$ & $0.925 \pm 0.2$ & $0.401 \pm 0.6$ \\
diversity & Xylophagous & $1.204 \pm 0.3$ & $1.681 \pm 0.2$ & $1.355 \pm 0.4$ & $1.627 \pm 0.5$ & $1.575 \pm 0.2$ & $1.198 \pm 0.2$ \\
& Predators & $1.366 \pm 0.1$ & $1.312 \pm 0.4$ & $1.388 \pm 0.5$ & $1.690 \pm 0.4$ & $1.834 \pm 0.3$ & $1.644 \pm 0.2$ \\
& Saprophagous & $0.566 \pm 0.8$ & $1.190 \pm 0.6$ & $1.167 \pm 0.1$ & $1.307 \pm 0.3$ & $1.373 \pm 0.5$ & $1.221 \pm 0.2$ \\
Evenness & Herbivores & $0.848 \pm 0.2$ & $0.792 \pm 0.1$ & $0.735 \pm 0.2$ & $0.706 \pm 0.1$ & $0.685 \pm 0.3$ & $0.872 \pm 0.2$ \\
& Xylophagous & $0.427 \pm 0.1$ & $0.652 \pm 0.0$ & $0.549 \pm 0.1$ & $0.648 \pm 0.3$ & $0.679 \pm 0.2$ & $0.672 \pm 0.2$ \\
& Predators & $0.479 \pm 0.1$ & $0.851 \pm 0.1$ & $0.531 \pm 0.3$ & $0.645 \pm 0.2$ & $0.741 \pm 0.2$ & $0.693 \pm 0.1$ \\
& Saprophagous & $0.830 \pm 0.2$ & $0.946 \pm 0.0$ & $0.724 \pm 0.2$ & $0.834 \pm 0.1$ & $0.916 \pm 0.1$ & $0.979 \pm 0.0$ \\
\hline
\end{tabular}


Fig. 2 - Canonical correspondence analysis (CCA) biplot for the beetles communities at 17 sites constrained by twelve microhabitat variables.

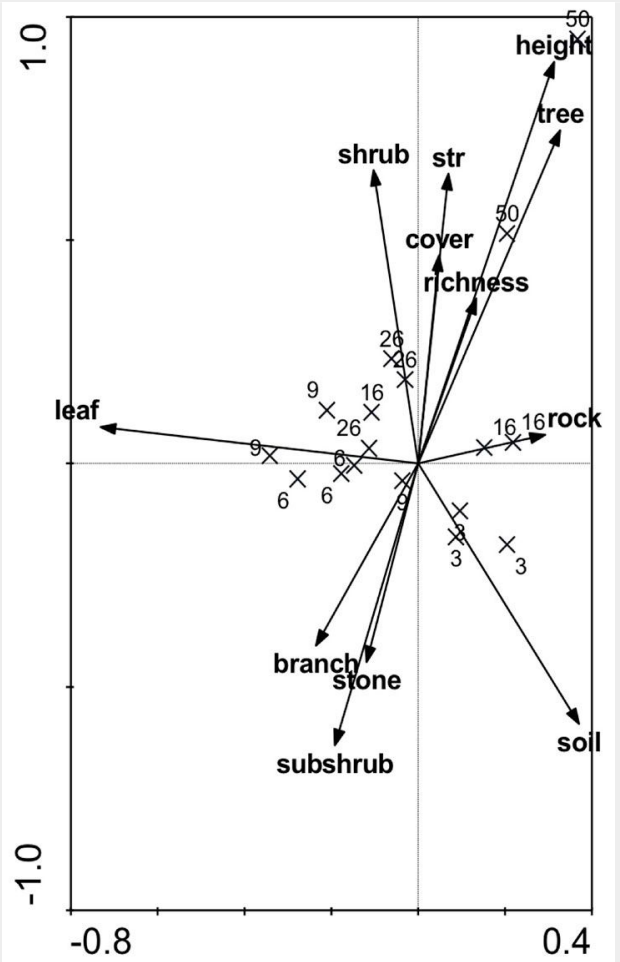

other guild. Predators (25.9\%), herbivores (10.3\%), saprophages (8.1\%), and granivores $(0.2 \%)$ were also represented. Predator and xylophagous beetles were more abundant in the earliest successional stages in comparison with the other successional stages $(\mathrm{df}=5, \mathrm{p}<0.0001, \mathrm{~F}=12.503$ and $\mathrm{F}=13.617$, respectively). Concerning interactions with microhabitat variables, abundances of both feeding groups was associated with only bare soil cover (xylophagous: $\mathrm{R}^{2}=$ $0.140 ; \mathrm{F}=10.736 ; \mathrm{P}=0.002$; predators: $\mathrm{R}^{2}=$ $0.286 ; \mathrm{F}=26.398 ; \mathrm{p}<0.0001$ ).

Another guild, herbivores had a contrary trend to xylophagous and predator beetles over the successional gradient. Their abundance tended to increase with successional gradient, whereas it was smallest at the control site. This site differs significantly from sites burned 16 and 26 years previously $(F=3.180, d f=5, p=0.013)$. Herbivore abundance was positively correlated with rock cover $\left(R^{2}=0.160, F=12.598, p=\right.$ 0.001 - Fig. 3).

Abundance of saprophagous beetles was higher at sites burned 3 and 9 years previously and lower at site 16 years old and later successional stages. No significant dif-
Fig. 3 - The changes of feeding groups of beetles depending on successional gradient and interactions between abundance of feeding groups and significant microhabitat variables.
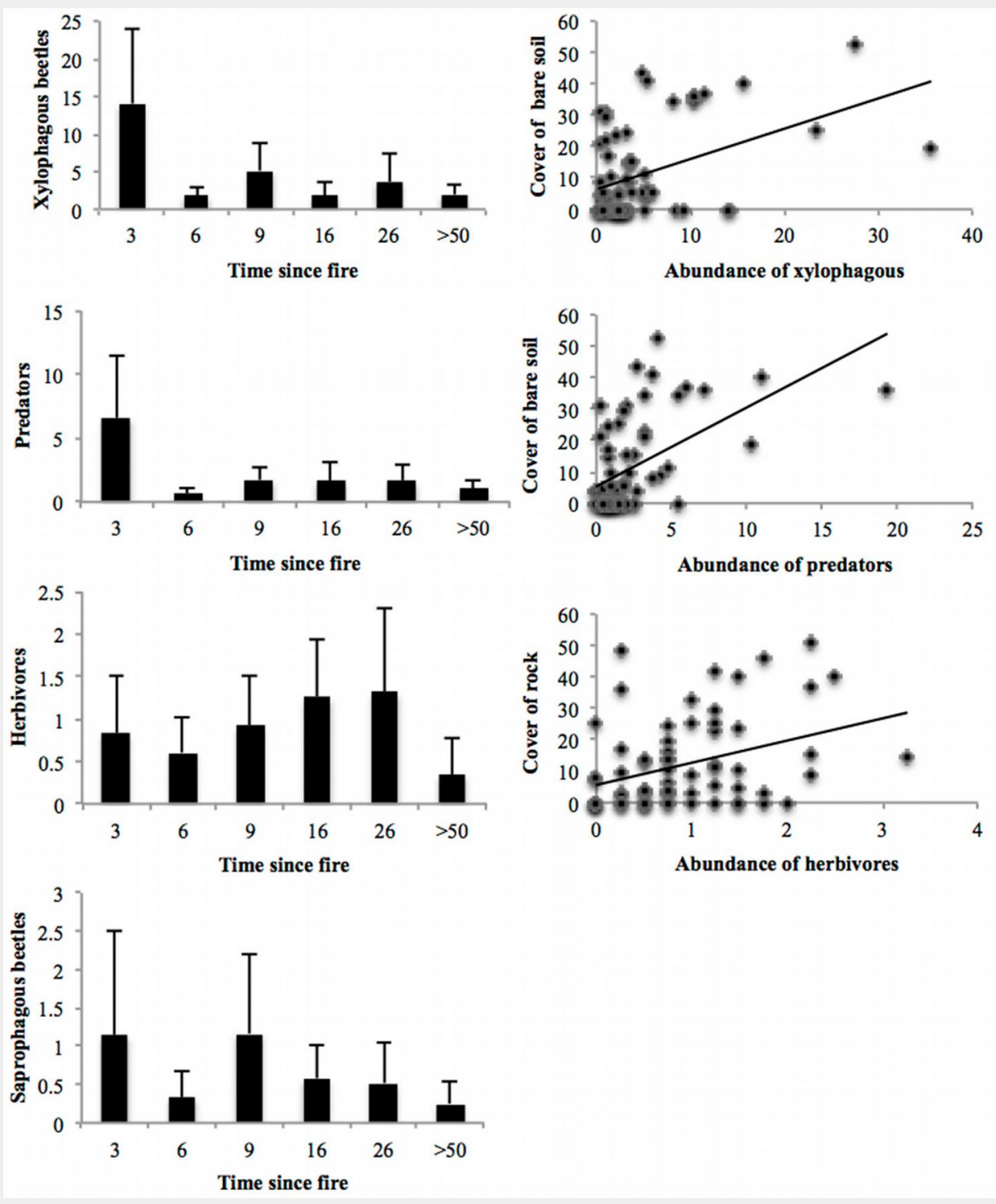

Abundance of herbivores 
ferences were found among successional stages in terms of abundance (Fig. 3). No microhabitat variables were related to the abundance of saprophagous beetles.

\section{Discussion}

Fire destroyed stands in a very short time, causing drastic changes in the habitat structure of faunal communities. Forest ecosystems characterized by a large extension of pine trees and a layer of humus and dead leaves on the ground are transformed to areas with a simpler vegetation structure with no tree cover and a large extension of bare ground after fire (Mateos et al. 2011). For resilient ecosystems such as low-altitude Mediterranean forests, plant communities have some adaptive traits that enable them to regenerate rapidly after fire (Keeley 1986, Hanes 1971). Some studies from these ecosystems show that faunistic groups recover within a short time after fire due to their high resilience as well (Sgardelis \& Margaris 1993, Stamou et al. 2004).

According to several studies conducted in the Mediterranean basin, the seasonality of the Mediterranean climate (Sgardelis et al. 1995) and post-fire age of the stands (Radea \& Arianoutsou 2000) are two important factors that affected arthropod fauna. The activity rates of certain insect groups after fire increase rapidly and time since fire is one of the main factors determining the dynamics and structure of the community (Muona \& Rutanen 1994, SaintGermain et al. 2004). The results obtained in this investigation are in agreement with these studies that beetle communities displayed change depending on the successional gradient after fire. The earliest successional stage supported a greater number of individuals. At this stage, beetle abundance was the highest and it decreased depending on the successional gradient. In studies performed in fire-induced ecosystems, similar results were obtained (Hjältén et al. 2010, Moretti et al. 2004). The higher abundancy in earlier stages could arise from different groups' attraction to post-fire areas. Some groups, such as heliophilous and floricolous insects, profit from the reduced tree cover and the number of flowering plants (Moretti et al. 2004). Muona \& Rutanen (1994) stated that many groups of beetles in different guilds benefited from the fire-caused changes in availability of microhabitats and foods. Campbell et al. (2007) stated about pollinator beetle groups that floral visitors increased in abundance and species richness in burn treatments because of the reduced density of overstorey trees and the increased amount of herbaceous plant growth.

Regarding the interaction between beetle community parameters and microhabitat variables, our results showed that the characteristics of the vegetation and litter layer play an important role in the community structure of beetles along the succes- sion. As an autosuccession process in pine forests of the Mediterranean basin, plant species composition does not differ among successional stages (Trabaud 1994, Tavsanoglu \& Gürkan 2009). After fire, plant communities return to a stage similar to that existing before the fire (Trabaud 2000). Thereby habitat change in the successional process is much more dependent on the characteristics of the vegetation and litter layer. The changes in beetle community structure and dynamics in successional gradient substantially depend on these variations among successional sites. The variables that increased with successional gradient and reached their maximum in the mature forest, such as height of vegetation, stratification, tree cover, and plant species richness, were important for beetle communities in the climax community. At the middle and late successional sites, beetle communities were correlated with shrub and leaf cover. The importance of leaf litter and shrub cover for beetle communities was revealed in the study performed by York (2002).

Xylophagous and predator beetles, which were two guilds that benefited from the post-fire conditions, had the highest abundance in the earliest stage as well. Since wood-eating insects prefer damaged or recently dead trees in burned areas, this group is frequently associated with fire (Santoro et al. 2001, McHugh et al. 2003, Azeria et al. 2012). In some studies significant outbreaks caused by xylophagous insects were recorded in burned areas (Santolamazza-Carbone et al. 2011). This higher activity could be due to immigration of helio- and anthophilus species from surrounding intact stands (Moretti \& Barbalat 2004). Open surfaces with woody materials and higher temperature than the surrounding areas attracted many species to recently burned areas (Toivanen \& Kotiaho 2007, Wikars 1992). Another abundant group, predators, consist of the families Carabidae, Staphylinidae, and Cleridae. The higher activation level of predators in the earliest stage resulted substantially from the families Carabidae and Cleridae. Carabidae is a group that has been frequently focused on in studies about habitat changes after disturbances (Hanula \& Wade 2003, Magura et al. 2003, Ulyshen et al. 2006). Cook \& Holt (2006) stated that fire might not have dramatic effects on ground beetles on prairies. They were represented in greater numbers in recently burned areas through colonization by opportunistic species (Fernández Fernández \& Salgado Costas 2004). Cleridae are a group known as predators on wood-boring beetle larvae (Booth et al. 1990). It is not surprising to find them in greater numbers at the earliest successional site in correlation with wood-eating beetles. Saint-Germain et al. (2004) found similar results regarding these groups and stated that saproxylic species (Buprestidae, Cerambycidae, and Scolytidae) depend on largely dead wood, and subcortical predators (Cleridae) were represented in great number of individuals in the earliest successional stages. In this study we found that abundance of $\mathrm{Co}$ leoptera guilds was substantially associated with surface characteristics. In particular, bare soil cover was determined the most important microhabitat variable because it was associated with abundance of total beetles, xylophagous species, and predators. Apigian et al. (2006) stated similarly that increased bare mineral soil resulting from loss of duff and litter layers was the most significant variable explaining the change in beetle communities.

Contrary to xylophagous and predator beetles, herbivore abundance exhibited a rising trend with successional gradient, surpassing the higher value in the earliest stage. Species richness and diversity were highest in the middle successional stage. Herbivore abundance was associated with just one microhabitat variable, rock cover. Leaf quality, habitat structure, and habitat heterogeneity are variables reported to affect the herbivore community structure (Kim \& Holt 2012), but the positive interaction with rock cover is surprising. Rock cover is not a microhabitat variable that can associate with the herbivore abundance directly. Both herbivore abundance and rock cover had higher values in site burned 16 and 26 years ago. Detected correlation may have resulted from analogous changes of these two independent variables with successional gradient. But then, if we look at different point of view, high cover of rock in late successional stages may have contributed to increase of herbivore abundance. The study area has a higher productivity in comparison with similar sites in the eastern Mediterranean region because of peculiar local climatic conditions (Tavsanoglu \& Gürkan 2009). Bare rock areas can represent forest openings in dense closed vegetation of late successional stages. Herbivores may have positively responded to these forest openings. Middle and late successional stages with high abundance of herbivores, at the same time, were very important for species richness, species diversity and evenness of all guilds and total beetles. The number of specialist beetle species was also higher in the middle successional stages as compared with the other stages. Kaynas (2008) stated in her study performed at the same sites that plant species richness, height of vegetation, and stratification increase along the successional gradient. The middle and late successional stages are more complex habitats including diverse microhabitats compared to the earlier ones, as the architectural complexity increases with vegetation height (Lawton 1983). Habitat permanence, habitat complexity, resource availability, and diversity increase with successional gradient (Brown 1985). Habitat complexity was a powerful predictor of the species richness and abundance of pitfalltrapped beetles (Lassau et al. 2005). Gard- 
ner et al. (1995) stated that arthropod diversity was substantially influenced by the habitat components related to plant architectural and vertical diversity. The middle and late successional stages had an advantage over the climax community because they were lacking a crown layer. Complex habitat structure as well as the absence of a closed crown layer increased species richness of these groups in these habitats. Lower species diversity for some insect groups in closed canopy mature forest, as compared to successional sites burned at different times, was reported in several studies (Koivula et al. 2002).

The high species richness at the middle and late successional sites might also be related to the pattern of shrub patchiness in the landscape. Shelef \& Groner (2011) stated that shrubs create the main driving force behind the beetle movement pattern and spatial distribution. Shrub shading might be an important factor for their thermoregulation in the Mediterranean climate, characterized by hot and dry summer seasons. Middle and late successional stages dominated by shrubs and short trees might create optimal conditions for insect species, providing protection against adverse environmental conditions and predation, as well as greater levels of prey items (Lassau et al. 2005).

\section{Conclusions}

No negative effects on the community structure of beetles caused by habitat changes after fire were determined. Beetle communities of $P$. brutia forests appear to be resilient to fire as in many other fireinduced ecosystems (Parr et al. 2004, Abbott et al. 2003, Andersen \& Müller 2000). $P$. brutia forests in southwest Anatolia comprise a mosaic of forest patches of different ages after fire. Earlier successional stages were gaps of different size among mature forests, thus ensuring the maintenance of open habitat species in the area. Middle and late successional stages had high habitat heterogeneity and are of particular importance to sustain the species richness of beetles. Beside successional stages, unburned, mature $P$. brutia forests act as source areas for colonization of species (Wikars \& Schimmel 1998). The protection of this mosaic structure of the landscape is very important to sustain high species richness of $P$. brutia forests.

\section{Acknowledgements}

Many thanks to Çagatay Tavsanoglu, Anil Soyumert, Oksal Macar, Filiz Yeni, Yasin Ilemin, Okan Ürker, Hüseyin Yilmaz, Sinan Kaynas and many undergraduate students for their help during the fieldwork, Atilla Küçükala, the Director of Marmaris National Park for his logical support, and Forest Management Directorate of Marmaris, Directorate of Marmaris National Park, and Aksaz Military Marine Base Command for allowing to conduct this study in the areas under their responsibility. The study was financially supported by Hacettepe University Scientific Research Unit (Project no: 02.02.601.004).

\section{References}

Abbott I, Burbidge T, Strehlow K, Mellican A, Wills $A$ (2003). Logging and burning impacts on cockroaches, crickets and grasshoppers, and spiders in Jarrah forest, Western Australia. Forest Ecology and Management 174: 383-399. doi: 10.1016/S0378-1127(02)00058-0

Andersen AN, Müller WJ (2000). Arthropod responses to experimental fire regimes in an Australian tropical savannah: ordinal-level analysis. Austral Ecology 25: 199-209. - doi: 10.1046/ j.1442-9993.2000.01038.x

Apigian KO, Dahlsten DL, Stephens S (2006). Fire and fire surrogate treatment effects on leaf litter arthropods in a western Sierra Nevada mixed-conifer forest. Forest Ecology and Management 221: 110-122. - doi: 10.1016/j.foreco.2005. 09.009

Azeria ET, Ibarzabal J, Hébert C (2012). Effects of habitat characteristics and interspecific interactions on co-occurrence patterns of saproxylic beetles breeding in tree boles after forest fire: null model analyses. Community Ecology 168 : 1123-1135. - doi: 10.1007/s00442-011-2180-0

Booth RG, Cox ML, Madge RB (1990). IIE guides to insects of importance to man. Coleoptera. International Institute of Entomology, CAB International, Wallingford, UK, pp. 384. [online] URL: http://www.cabdirect.org/cabdirect/abstr act/19911153349

Brown VK (1985). Insect herbivores and plant succession. Oikos 44 (1): 17-22. - doi: 10.2307/35 44037

Campbell JW, Hanula JL, Waldrop TA (2007). Effects of prescribed fire and fire surrogates on floral visiting insects of the blue ridge province in North Carolina. Biological Conservation 134: 393-404. - doi: 10.1016/j.biocon.2006.08.029

Cook WM, Holt RD (2006). Fire frequency and mosaic burning effects on a tallgrass prairie ground beetle assemblage. Biodiversity and Conservation 15: 2301-2323. - doi: 10.1007/s105 31-004-8227-3

Fernández Fernández MM, Salgado Costas JM (2004). Recolonization of a burnt pine forest (Pinus pinaster) by Carabidae (Coleoptera). European Journal of Soil Biology 40: 47-53. doi: 10.1016/j.ejsobi.2004.01.003

Gardner SM, Cabido MR, Valladares GR, Sandra D (1995). The influence of habitat structure on arthropod diversity in Argentine semi-arid Cahco forest. Journal of Vegetation Science 6: 349-356. - doi: 10.2307/3236234

Hanes TL (1971). Succession after fire in the chaparral of southern California. Ecological Monographs 41: 27-52. - doi: 10.2307/1942434

Hanula JL, Wade DD (2003). Influence of longterm dormant-season burning and fire exclusion on ground-dwelling arthropod populations in longleaf pine flatwoods ecosystems. Forest Ecology and Management 175: 163-184. - doi: 10.1016/S0378-1127(02)00130-5

Hjältén J, Gibb H, Ball JP (2010). How will lowintensity burning after clear-felling affect midboreal insect assemblages? Basic and Applied Ecology 11: 363-372. - doi: 10.1016/j.baae.2009.1 2.012
Kaynas BY (2008). Studies on long-term effects of fire on small mammal community and changes of community structure after fire in Pinus brutia forest ecosystems, PhD Thesis, Institute of Natural Sciences, Hacettepe University, Turkey, pp. 112. [in Turkish with English abstract]

Kaya Z, Raynal DJ (2001). Biodiversity and conservation of Turkish forest. Biological Conservation 97: 131-141. - doi: 10.1016/S0006-3207(00) 00069-0

Kim TN, Holt RD (2012). The direct and indirect effects of fire on the assembly of insect herbivore communities: examples from the Florida scrub habitat. Oecologia 168: 997-1012. - doi: 10.1007/s00442-011-2130-x

Keeley JE (1986). Resilience of Mediterranean shrub communities to fires. In: "Resilience in Mediterranean-type ecosystems" (Dell B, Hopkins AJM, Lamont BB eds). Dr W Junk Publishers, Dordrecht, Netherlands, pp. 95-111. - doi: 10.1007/978-94-009-4822-8_7

Koivula M, Kukkonen J, Niemelä J (2002). Boreal carabid-beetle (Coleoptera, Carabidae) assemblages along the clear-cut originated succession gradient. Biodiversity and Conservation 11: 1269-1288. - doi: 10.1023/A:1016018702894 Lassau SA, Hochuli DF, Cassis G, Reid CAM (2005). Effects of habitat complexity on forest beetle diversity: do functional groups respond consistently? Diversity and Distributions 11: 7382. - doi: 10.1111/j.1366-9516.2005.00124.x Lawton JH (1983). Plant architecture and the diversity of phytophagous insects. Annual Review of Entomology 28: 23-39. - doi: 10.1146/ annurev.en.28.010183.000323

Leach E, Nakamura A, Turco F, Burwell CJ, Catterall CP, Kitching RL (2013). Potential of ants and beetles as indicators of rainforest restoration: characterising pasture and rainforest remnants as reference habitats. Ecological Management and Restoration 14: 202-209. - doi: 10.1111/emr.12068

Magura T, Tóthmérész B, Elek Z (2003). Diversity and composition of carabids during a forest cycle. Biodiversity and Conservation 12: 73-85. doi: 10.1023/A:1021289509500

Mateos E, Santos X, Pujade-Villar J (2011). Taxonomic and functional responses to fire and post-fire management of a Mediterranean $\mathrm{Hy}$ menoptera community. Environmental Management 48: 1000-1012. - doi: 10.1007/s00267011-9750-0

McHugh CW, Kolb TE, Wilson JL (2003). Bark beetle attacks on Ponderosa pine following fire in Northern Arizona. Environmental Entomology 32 (3): 510-522. - doi: 10.1603/0046-225X32.3.510

Moretti M, Barbalat S (2004). The effects of wildfires on wood-eating beetles in deciduous forests on the southern slope of the Swiss Alps. Forest Ecology and Management 187: 85-103. doi: $10.1016 /$ S0378-1127(03)00314-1

Moretti M, Obrist MK, Duelli P (2004). Arthropod biodiversity after forest fires: winners and losers in the winter fire regime of the southern Alps. Ecography 27: 173-186. - doi: 10.1111/j.09067590.2004.03660.x

Moretti M, De Bello F, Roberts SPM, Potts SG (2009). Taxonomical vs. functional responses of bee communities to fire in two contrasting 
climatic regions. Journal of Animal Ecology 78: 98-108. - doi: 10.1111/j.1365-2656.2008.01462.x

Muona J, Rutanen I (1994). The short-term impact of fire on beetle fauna in boreal coniferous forest. Annales Zoologici Fennici 31: 109-121. [online] URL: http://www.jstor.org/stable/2373 5504

Parr CL, Robertson HG, Biggs HC, Chown SL (2004). Response of African savanna ants to long-term fire regimes. Journal of Applied Ecology 41: 630-642. - doi: 10.1111/j.0021-8901.2004. 00920.x

Prodon R, Fons R, Athias-Binche F (1987). The impact of fire on animal communities in Mediterranean Area. In: "The Role of Fire in Ecological Systems" (Trabaud L ed). SPA Academic Publishing, The Hague, Netherlands, pp. 121-157. Radea C, Arianoutsou M (2000). Cellulose decomposition rates and soil arthropod community in a Pinus halepensis Mill. forest of Greece after a wildfire. European Journal of Soil Biology 36: 57-64. - doi: 10.1016/S1164-5563(00)01 045-1

Saint-Germain M, Drapeau P, Hébert C (2004). Comparison of Coleoptera assemblages from a recently burned and unburned black spruce forests of northeastern North America. Biological Conservation 118: 583-592. - doi: 10.1016/j. biocon.2003.10.007

Santolamazza-Carbone S, Pestaña M, Vega JA (2011). Post-fire attractiveness of maritime pines (Pinus pinaster Ait.) to xylophagous insects. Journal of Pest Science 84 (3): 343-353. doi: 10.1007/s10340-011-0359-0

Santoro AE, Lombardero MJ, Ayres MP, Ruel JJ (2001). Interactions between fire and bark beetles in an old growth pine forest. Forest Ecology and Management 144: 245-254. - doi: 10.1016/S0378-1127(00)00389-3

Sgardelis SP, Margaris NS (1993). Effects of fire on soil microarthropods of a phryganic system. Pedobiologia 37: 83-94.

Sgardelis SP, Pantis JD, Argyropoulou MD, Stamou GP (1995). Effects of fire on soil macroinertebrates in a Mediterranean phryganic ecosystem. International Journal of Wildland Fire 5: 113-121. - doi: 10.1071/WF9950113

Shelef O, Groner E (2011). Linking landscape and species: effect of shrubs on patch preference of beetles in arid and semi-arid ecosystems. Journal of Arid Environments 75: 960-967. - doi: 10.1016/j.jaridenv.2011.04.016

Siemann E, Haarstad J, Tilman D (1999). Dynamics of plant and arthropod diversity during old field succession. Ecography 22: 406-414. - doi: 10.1111/j.1600-0587.1999.tbo0577.x

Siemann E (1998). Experimental tests of effects of plant reproductivity and diversity on grassland arthropod diversity. Ecology 79 (6): 20572070. - doi: 10.1890/0012-9658(1998)079[2057: ETOEOP]2.0.CO;2

Southwood TRE, Brown VK, Reader PM (1979). The relationships plant and insects diversities in succession. Biological Journal of Linnean Society 12: 327-348. - doi: 10.1111/j.1095-8312.1979.tb $00063 . x$

Sutherland WJ (2006). Ecological census techniques, a handbook ( $2^{\text {nd }}$ edn). Cambridge University Press, Cambridge, UK, pp. 446. [online] URL: http://books.google.com/books?id=rTJdia 64ACMC

Stamou GP, Stamou GV, Papatheodorou EM, Argyropoulou MD, Tzafestas SG (2004). Population dynamics and life history tactics of arthropodsfrom Mediterranean-type ecosystems. Oikos 104: 98-108. - doi: 10.1111/j.0030-1299.2004. 12382.x

Tavsanoglu C, Gürkan B (2009). Post-fire regeneration of a Pinus brutia (Pinaceae) forest in Marmaris National Park, Turkey. International Journal of Botany 5: 107-111. - doi: 10.3923/ijb. 2009.107.111

Ter Braak CJF, Smilauer P (2002). Canoco for Windows version 4.5. Biometris-Plant Research International, Wageningen, Netherlands.

Thanos CA, Marcou S (1989). Early post-fire regeneration in Pinus brutia forest ecosystems of Samos island (Greece). Acta Oecologica 10 (1): 79-94.

Toivanen T, Kotiaho JS (2007). Mimicking natural disturbances of boreal forests: the effects of controlled burning and creating dead wood on beetle diversity. Biodiversity and Conservation 16: 3193-3211. - doi: 10.1007/s10531-007-9172-8 Trabaud L (2000). Post-fire regeneration of Pinus halepensis forests in the West Mediterranean.
In: "Ecology, Biogeography and Managenement of Pinus halepensis and Pinus brutia Forest Ecosystems in the Mediterranean Basin (Ne'eman G, Trabaud L eds). Backhuys Publishers, Leiden, The Netherlands, pp. 257-268.

Trabaud L (1994). Postfire plant community dynamics in the Mediterranean Basin. In: "The Role of Fire in Mediterranean-Type Ecosystems" (Moreno JM, Oechel WC eds). SpringerVerlag, New York, USA, pp. 1-15. - doi: 10.1007/ 978-1-4613-8395-6_1

Ulyshen MD, Hanula JL, Horn S, Kilgo JC, Moorman CE (2006). The response of ground beetles (Coleoptera: Carabidae) to selection cutting in a South Carolina bottomland hardwood forest. Biodiversity and Conservation 15: 261-274. - doi: 10.1007/s10531-004-6899-3

Whelan RJ (1995). The ecology of fire. Cambridge University Press, Cambridge, UK, pp. 346.

Wikars L-O (1992). Forest fires and insects. Entomologisk Tidskrift 113: 1-11. [in Swedish]

Wikars L-O, Schimmel J (1998). Effects of experimental burning on ground-living invertebrates in a Swedish pine forest: interactions between fire-severity and logging. In: Proceedings of the " 3 rd International Conference on Forest Fire Research, $14^{\text {th }}$ Conference on Fire and Forest Meteorology" (Viegas DX ed). Luso (Coimbra, Portugal) 16-20 Nov 1998, vol. II, pp. 1447-1464. Wikars L-O, Schimmel J (2001). Immediate effects of fire-severity on soil invertebrates in cut and uncut pine forests. Forest Ecology and Management 141: 189-200. - doi: 10.1016/S03781127(00)00328-5

Wikars L-O (2002). Dependence on fire in woodliving insects: an experiment with burned and unburned spruce and birch logs. Journal of Insect Conservation 6: 1-12. - doi: 10.1023/A:1015 734630309

York A (2002). Pyrophilic or pyrophobic? The response of forest beetle communities to an altered fire regime. In: Proceeding of Conference "Forest Fire Research and Wildland Fire Safety" (Viegas X ed). Luso, Coimbra (Portugal) 18-23 Nov 2002. Millpress, Rotterdam, Netherlands. [CD-ROM] 